\title{
A diversity world record in a grassland at Oaxaca, Mexico
}

\section{creative commons}

\section{Botanical Sciences} 95 (1): 1-7, 2017

DOI: 10.17129/botsci.689

Copyright: (C) 2017 Martorell et al. This is an open access article distributed under the terms of the Creative Commons Attribution License, which permits unrestricted use, distribution, and reproduction in any medium, provided the original author and source are credited.

Author contributions: All authors collected the data and wrote the manuscript. Carlos Martorell and Diego GarcíaMeza conducted the statistical analyses.

Departamento de Ecología y Recursos Naturales, Facultad de Ciencias, Universidad $\mathrm{Na}$ cional Autónoma de México, Ciudad de México, Mexico. *Corresponding author: martorell@ciencias.unam.mx

\author{
Carlos Martorell*, Verónica Zepeda, Alejandra Martínez-Blancas, Diego \\ García-Meza and Fernando Pedraza
}

\section{Abstract}

Background: Plant richness world-records have been reported to occur either in tropical rainforests, or, at smaller spatial scales, in chronically disturbed grasslands. The tight relationship between scale and record richness suggests that there is an unyielding limit to diversity.

Hypotheses: If such limit exists, current records should hardly be beaten. Chronic disturbance in grasslands allows richness to approach the limit.

Studied species: All vascular plants at the study site.

Study site and years of study: A natural, semiarid grassland at Concepción Buenavista, Oaxaca, Mexico, in 2012 and 2014.

Methods: At 21 sites we recorded species richness in randomly sampled $0.1 \times 0.1 \mathrm{~m}$ quadrats, and measured chronic disturbance caused by different agents. We estimated the maximum richness at each site through maximum likelihood. At one site we searched for high richness quadrats.

Results: The study site shares the current world record of plant richness at the $0.1 \times 0.1 \mathrm{~m}$ scale with 25 species. The estimated maximum diversity at each site decreased with land degradation, but had a maximum at intermediate-high levels of livestock activity.

Conclusions: Our results support the idea of a hard limit to species richness, and thus theories of plant coexistence that envisage such limit. Our study site shares attributes with other record-holding grasslands, such as severe resource limitations and chronic disturbance by ungulates, suggesting that these conditions promote high species richness. We hope that, by reporting this diversity record, we also help to change the notion that Mexican grasslands are secondary communities having a negligible biological value.

Keywords: Chronic anthropogenic disturbance, semiarid grassland, species richness, coexistence, intermediate disturbance hypothesis.

\section{Un récord mundial de diversidad en un pastizal de Oaxaca, México \\ Resumen}

Antecedentes: Los récords mundiales de riqueza de especies de plantas se han reportado en selvas perennifolias o, en escalas pequeñas, en pastizales con disturbio crónico. La relación estrecha entre escala y riqueza récord sugiere la existencia de un límite inviolable para la diversidad.

Hipótesis: Si tal límite existe, los récords actuales difícilmente serán rotos. El disturbio crónico permite que la riqueza de los pastizales se acerque al límite.

Especies en estudio: Las plantas vasculares en el sitio de estudio.

Sitio de estudio y fechas: Un pastizal natural semiárido, Concepción Buenavista, Oaxaca, 2012 y 2014.

Métodos: En 21 sitios registramos la riqueza de especies en cuadros de $0.1 \times 0.1 \mathrm{~m}$ y medimos el disturbio crónico causado por distintos agentes. Estimamos la diversidad máxima de cada sitio por verosimilitud máxima. En un sitio buscamos los cuadros con mayor riqueza.

Resultados: Nuestro sitio comparte el récord de riqueza en la escala de $0.1 \times 0.1 \mathrm{~m}$ con 25 especies. La riqueza máxima estimada se redujo con la degradación del suelo, pero alcanzó un máximo en un disturbio medio-alto por ganado.

Conclusiones: Nuestros resultados apoyan la idea de que existe un límite inviolable a la riqueza de especies, y consecuentemente a las teorías que lo predicen. Nuestro sitio comparte atributos con otros pastizales que detentan récords, como limitaciones severas de recursos y disturbio crónico por ungulados, condiciones que parecen promover altas diversidades. Esperamos que, reportando este récord, contribuyamos a cambiar la noción de que los pastizales mexicanos son comunidades secundarias sin valor biológico.

Palabras Clave: Disturbio antropogénico crónico, pastizales semiáridos, riqueza de especies, coexistencia, hipótesis del disturbio intermedio. 
iodiversity is perhaps the most valuable asset on planet Earth. As such, conservation and research efforts are usually devoted to sites with outstanding species richness (Myers et al. 2000). Among terrestrial ecosystems, tropical rainforests have become an icon of biodiversity, and for good reasons: they not only harbor a huge fraction of the species on the planet, but also the largest number of species per square kilometer (Dirzo \& Raven 2003). However, as it happens so frequently in ecology, everything is a matter of scale. If the area over which the number of plant species is recorded becomes small, tropical rainforests retain their preeminence down to $100 \mathrm{~m}^{2}$. At smaller scales, grasslands become the undisputed holders of plant-richness world records. The figures are surprising: grasslands may accommodate up to 89 plant species in a square meter, or even 5 species in a square centimeter (Wilson et al.2012). One outstanding attribute of all record-holding grasslands is that they have been subjected to millennia of chronic disturbance by mowing or ungulate grazing (Wilson et al. 2012).

Species-rich communities are an endless source of awe and perplexity for biologists. Early studies on species interactions made it clear that species coexistence can only occur under restrictive conditions. Niche differentiation has been an all-time favorite hypothesis to explain coexistence, and much of the recent evidence seems to favor this proposition (Levine \& HilleRisLambers 2009, Adler et al. 2010, Chu \& Adler 2015). However, this raises the question of how there can be so many niches if plants depend on so few resources (Silvertown 2004).

The classic theory of niche-based coexistence suggests that there should be a "hard limit" to richness determined by the similarity of the species requirements and how finely niche space can be partitioned (e.g., Preston, 1962). Communities where richness matches that limit are called saturated. Alternative explanations for coexistence do not acknowledge such limit. This is the case of the hypothesis that local richness is largely determined by regional diversity, or of theories in which niche similarity does not necessarily preclude coexistence such as neutrality or Chesson's coexistence theory (Chesson, 2000; Hubbell, 2001).

Thus, determining whether communities are saturated, or whether a hard limit to richness exists, is an important task to screen among different models of species coexistence. Keeping the world records of plant richness is a relevant contribution in this direction. Wilson et al. (2012) compiled such information for different spatial scales. They found that the function relating the records to area fits Preston's (1962) canonical theory, which was developed on the assumption that communities are saturated. As they point out, if there are in fact saturated communities in nature, these are the ones in their database.

The known records will surely be beaten because it is highly unlikely that the richest places on Earth have been already surveyed (especially if we consider small scales). However, based on the close relationship between richness records and area, Wilson et al. propose that any new records should be near the current ones. Here we test this hypothesis, and analyze the role of chronic disturbance in promoting extremely high plant diversity in a species-rich grassland.

\section{Materials and Methods}

We worked in a semiarid grassland in Concepción Buenavista, Oaxaca, Mexico (Figure 1a). The climate is semiarid, with an annual precipitation of $578 \mathrm{~mm}$ and an annual mean temperature of $16.3{ }^{\circ} \mathrm{C}$ (Martorell \& Martínez-López 2014). One of the outstanding features of this community is that it develops on very thin (usually $<15 \mathrm{~cm}$ ) soils over a relatively impermeable tuff deposit. This community is probably the southernmost xeric grassland of North America, and is dominated by the same species or genera that characterize many of its northern counterparts (cf. Cruz-Cisneros \& Rzedowski, 1980). According to Mueller-Dumbois \& Ellenberg (1974) classification, the vegetation is a shortgrass prairie. We still do not know the total plant richness of this community. Our current list exceeds 200 species, but it is by no means exhaustive. We have found new species in our permanent plots almost every year since 2001 (For a sample of the community's richness please visit http://conabio.inaturalist.org/projects/plantas-de-concepcion-buenavista-oaxaca-mexico).

We recorded species richness in 210.5 ha sites occurring over a chronic anthropogenic disturbance gradient. Disturbance was measured through the Martorell \& Peters (2009) indices, which estimate the intensity of three disturbance agents: livestock raising, human activities and 
a

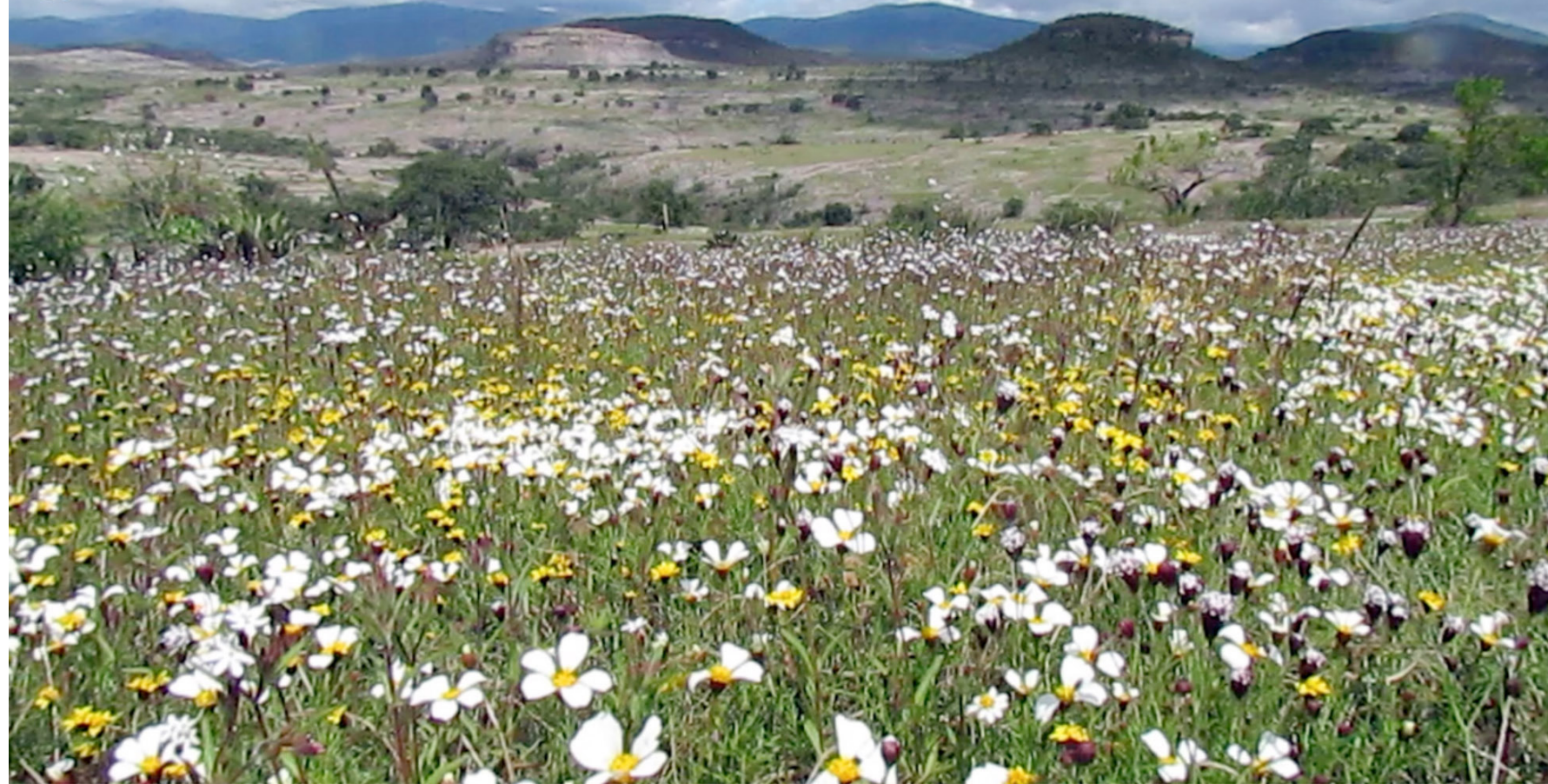
b 50 a

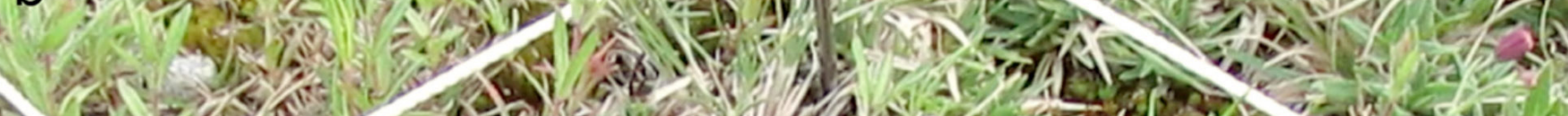
A (5) $\Rightarrow$ s.

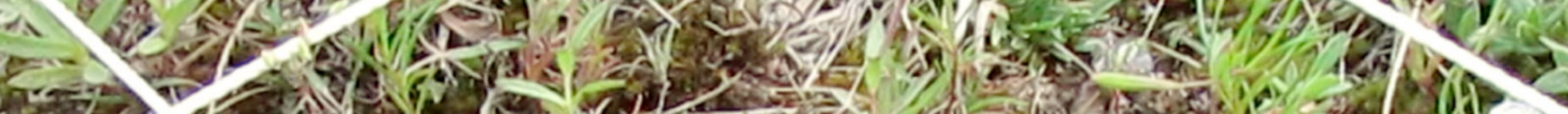

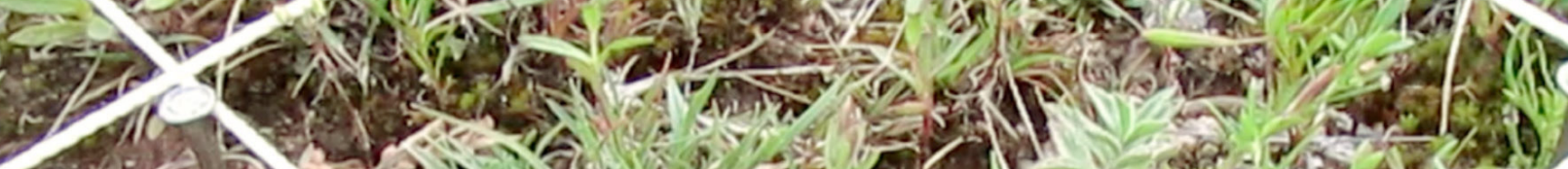

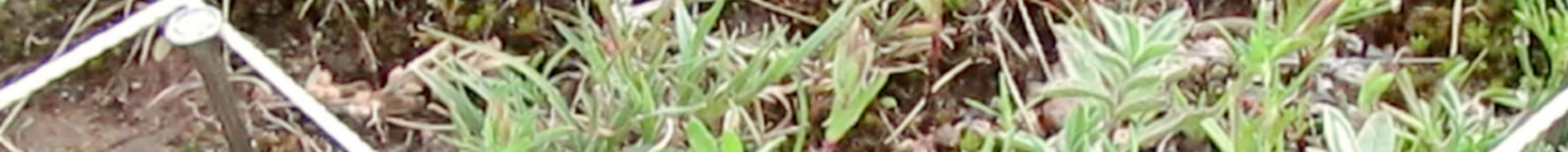

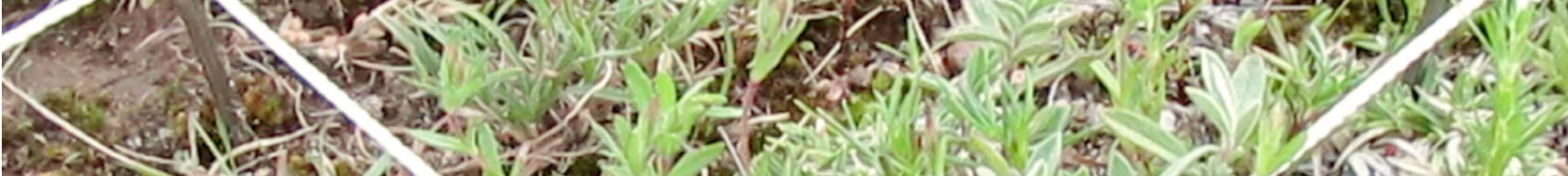

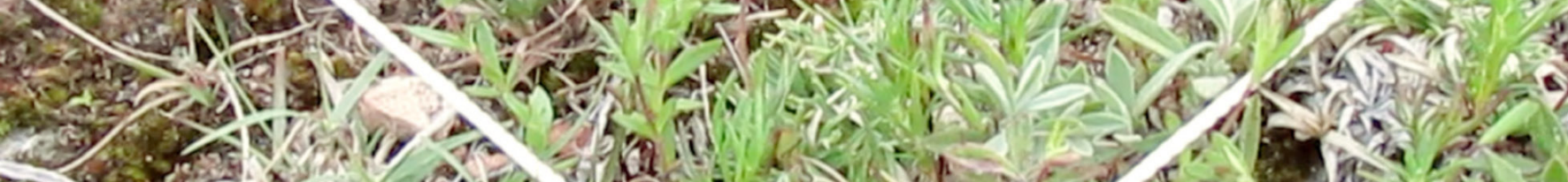

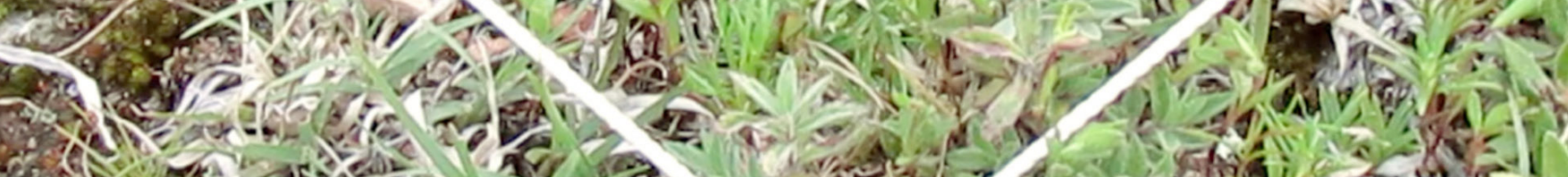

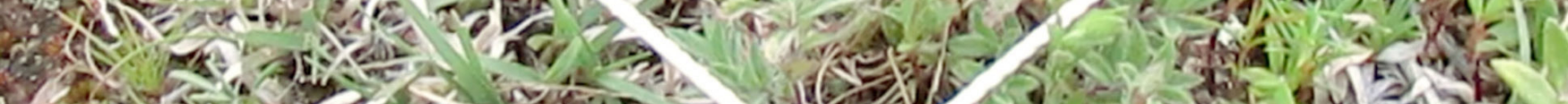

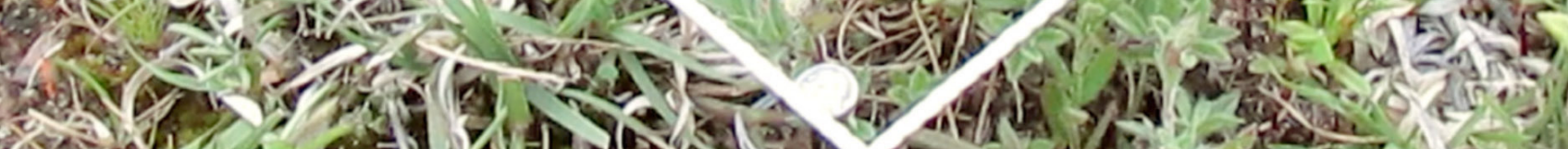
(5)

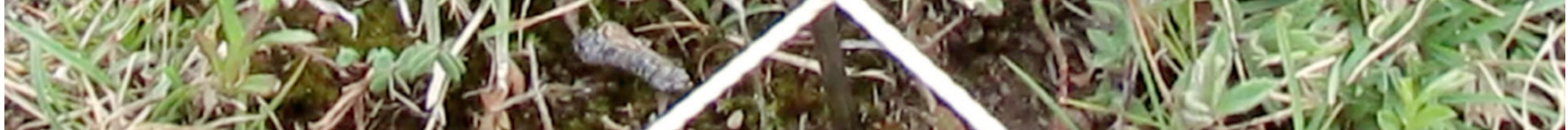

Figure 1. Vegetation at Concepción Buenavista. a) Landscape during the flowering season. b) The $0.1 \times 0.1 \mathrm{~m}$ quadrat with world record plant richness. 
land degradation. In eight $1 \times 1 \mathrm{~m}$ randomly-placed plots at each site, we surveyed 20 randomly selected $0.1 \times 0.1 \mathrm{~m}$ quadrats. We recorded the number of vascular plant species rooted in each of these quadrats.

The site with the largest richness had 94 species. This is not far from the 113 species recorded at Laelatu, Estonia, the site that holds the world record at the scale of $0.1 \times 0.1 \mathrm{~m}$ (Kull \& Zobel 1991). This suggested that our community was a candidate to test Wilson et al.'s proposition. Thus, in September 2014 we looked for the $0.1 \times 0.1 \mathrm{~m}$ quadrat with the largest number of vascular plant species at one of the sites where we had recorded a large species richness in 2012. Only plants rooted inside the quadrat were recorded. Because our sampling was non-random and followed no systematic procedure, it cannot be strictly replicated. As a measure of sampling effort, we can only state that it comprised about 10 man-hours.

To analyze the effect of disturbance on promoting high species richness, we first needed an estimate of the maximum richness in each site. To calculate this figure, we first tried a number of probability distributions to describe the frequency of $0.1 \times 0.1 \mathrm{~m}$ quadrats having different number of species. By means of the Akaike information criterion we determined that a gamma distribution performed best. We then estimated what the maximum observed richness at each site would be if we had sampled 1,000 $0.1 \times 0.1 \mathrm{~m}$ quadrats (i.e., $501 \times 1 \mathrm{~m}$ plots) using the same protocol described above. To do so, we obtained the 99.9 percentile of the gamma distribution fitted for each site. This estimated maximum richness (EMR) was then regressed separately on the measurement of each disturbance agent using generalized additive models (Wood, 2011).

\section{Results}

We found a $0.1 \times 0.1 \mathrm{~m}$ quadrat with 25 plant species (Figure $1 \mathrm{~b}$ ), meaning that the grassland of Concepción Buenavista currently shares the world record of plant richness with the grassland at Laelatu (Kull \& Zobel, 1991). The identities of the species recorded in this quadrat are reported in table 1. This figure was greater than the EMR for the site where we conducted the directed search (17.2 species), but was very similar to the EMR calculated for the richest site (24.9).

EMR diminished with land degradation $(P=0.035$, Figure $2 \mathrm{a})$, but reached its maximum at intermediate-high intensities of livestock raising $(P=0.028$, Figure $2 b)$. Human activities had no significant relation with maximum richness.

\section{Discussion}

Because we could not beat but only match the current record, our results support Wilson et al.'s conjecture that current estimations are close to the actual maxima. The intensity of disturbance caused by livestock and land degradation at the site where the record was found is close to that where the greatest EMR is expected. The maximum EMR is also close to the maximum richness that we observed. This suggests that the value that we observed is close to the actual maximum at the study grassland. We must bear in mind that our sampling was biased towards high-richness areas, while the previously reported records resulted from random sampling. Thus, a direct comparison cannot be made with other studies. Nevertheless, the findings reported in Wilson et al. (2012) are based on very heterogeneous methods and yet render a quite close relationship between area and record diversity. This suggests that sampling protocol may have a minor effect on maximum richness.

If future research confirms that the current records reflect more or less correctly what happens in nature, it would appear that there is a hard limit to species richness. Moreover, the species-area relationship found by Wilson et al. for such limit is quite strong $\left(R^{2}=0.976\right)$, so its confirmation would mean that there is something extremely predictable going on that calls for an explanation.

The relationship between disturbance and EMR is in line with what we know about individual-species responses to disturbance. Many of the species of our study grassland are known to increase in density with chronic disturbance (Martínez-Blancas 2014). Land degradation has a severe negative effect on the population density of several cacti, but many species are benefitted by livestock (Martorell \& Peters 2009). Land degradation at the study site results in exposed 
Figure 2. Relationship between the intensity of different chronic disturbance agents and estimated maximum richness at 21 sites in the grassland. The red dot corresponds to the site where the quadrat with 25 species was found.

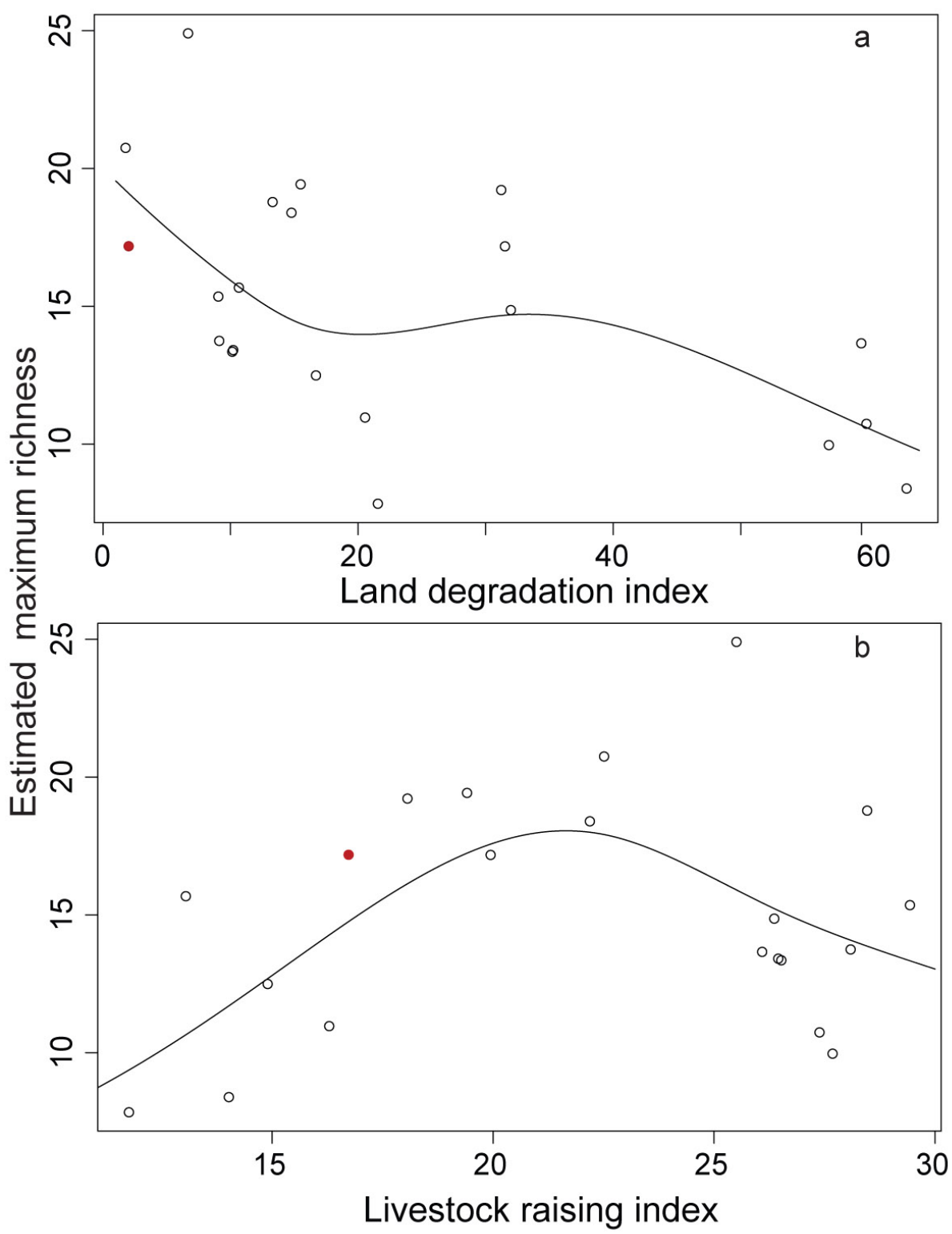

tuft where very few species can grow, reducing overall richness. In contrast, livestock raising may resemble grazing by the now-extinct large herbivores that roamed Concepción Buenavista (Guerrero-Arenas et al. 2010), and to which local plant species may have been adapted.

The plant community of Concepción Buenavista shares several attributes with other recordholding sites. All of them are meso- to oligotrophic grasslands with chronic disturbances due to grazing, mowing or fire (Wilson et al. 2012). The soils at our site are not necessarily nutrient poor, but due to their low depth they cannot retain water for long periods. The currently scarce biomass of our grassland is insufficient to sustain wildfires, but cattle, sheep and goat grazing is intense at the site. It must be noted that livestock was introduced to Oaxaca early in the sixteenth century (García 1996, Romero-Frizzi 1996). Thus, our results agree with the proposal that resource limitation and long-term disturbance promote high diversity.

We hope that, by reporting this record, we also help to change the notion shared by many biologists that Mexican grasslands are secondary communities having a negligible biological value. The grassland of Concepción Buenavista is not only home to a remarkable plant richness, but also to two microendemic species: Mammillaria hernandezii and Sedum oteroi. Both are incapable of growing in wooded areas. Their endemicity and habitat specificity indicate the great 
Table 1. Species composition of the richest quadrat in Concepción Buenavista, Oaxaca.

\begin{tabular}{ll}
\multicolumn{1}{c}{ Species } & \multicolumn{1}{c}{ Family } \\
\hline Aristida adscensionis L. & Poaceae \\
Bouteloua chondrosioides (Kunth) Benth. ex S. Watson & Poaceae \\
Bouteloua hirsuta Lag. & Poaceae \\
Bouteloua scorpioides Lag. & Poaceae \\
Buchnera pusilla Kunth & Orobanchaceae \\
Bulbostylis tenuifolia (Rudge) J.F. Macbr. & Cyperaceae \\
Crusea diversifolia (Kunth) W.R. Anderson & Rubiaceae \\
Cyperus seslerioides Kunth & Cyperaceae \\
Dalea sericea Lag. & Fabaceae \\
Digitaria bicornis (Lam.) Roem. \& Schult. & Poaceae \\
Drymaria leptophylla (Cham. \& Schltdl.) Fenzl ex Rohrb. & Caryophyllaceae \\
Florestina pedata (Cav.) Cass. & Asteraceae \\
Helianthemum glomeratum (Lag.) Lag. ex Dunal & Cistaceae \\
Heterosperma pinnatum Cav. & Asteraceae \\
Microchloa kunthii Desv. & Poaceae \\
Muhlenbergia phalaroides (Kunth) P.M. Peterson & Poaceae \\
Oxalis lunulata Zucc. & Oxalidaceae \\
Plantago nivea Kunth & Plantaginaceae \\
Salvia axillaris Moc. \& Sessé ex Benth. & Lamiaceae \\
Setaria parviflora (Poir.) Kerguelen & Poaceae \\
Stenandrium dulce (Cav.) Nees & Acanthaceae \\
Stevia ephemera Grashoff & Asteraceae \\
Tagetes micrantha Cav. & Asteraceae \\
Thymophylla aurantiaca (Brandegee) Rydb. & Asteraceae \\
Tridax coronopifolia (Kunth) Hemsl. & Asteraceae \\
\hline
\end{tabular}

antiquity of the grassland. The negative view of grasslands has resulted in a lack of protection and serious degradation. $95 \%$ of Mexican arid grasslands are overgrazed (SEMARNAT, 2003). Concepción Buenavista is adjacent to a Biosphere Reserve, but its polygon twists around the grassland, leaving it outside the protected area. At the time the reserve was established, nobody spoke for herbs. If biodiversity captivates biologists, grasslands should not be disregarded.

\section{Acknowledgements}

This project was funded by PAPIIT IN 220514. Agradecemos a la comunidad de Concepción Buenavista por su apoyo.

\section{Literature cited}

Adler PB, Ellner SP, Levine JM. 2010. Coexistence of perennial plants: an embarrassment of niches. Ecology Letters 13:1019-1029. DOI: 10.1111/j.1461-0248.2010.01496.x

Chesson P. 2000. Mechanisms of maintenance of species diversity. Annual Review of Ecology and Systematics 31:343-366. DOI: 10.1146/annurev.ecolsys.31.1.343

Chu C, Adler PB. 2015. Large niche differences emerge at the recruitment stage to stabilize grassland coexistence. Ecological Monographs 85:373-392. DOI: 10.1890/14-1741.1

Cruz-Cisneros R, Rzedowski J. 1980. Vegetación de la cuenca del río Tepelmeme, Alta Mixteca, Estado de Oaxaca (México). Anales de la Escuela Nacional de Ciencias Biológicas, Instituto Politéctico Nacional 22:19-84.

Dirzo R, Raven PH. 2003. Global state of biodiversity and loss. Annual Review of Environment and Resources 28:137-167. DOI: 10.1146/annurev.energy.28.050302.105532

García HA. 1996. La caprinocultura en la mixteca oaxaqueña. Orígenes. Ciencias 44:28-31.

Guerrero-Arenas R, Jiménez-Hidalgo E. y Santiago-Romero H. 2010. La transformación de los ecosistemas de la Mixteca Alta oaxaqueña desde el Pleistoceno tardío hasta el Holoceno. Ciencia y Mar 14:61-68. 
Received:

November 26th, 2015

Accepted:

February 18th, 2016
Hubbell SP. 2001. The unified neutral theory of biodiversity and biogeography. Princeton: Princeton University Press.

Kull K, Zobel M. 1991. High species richness in an Estonian wooded meadow. Journal of Vegetation Science 2: 715-718. DOI: $10.2307 / 3236182$

Levine JM, HilleRisLambers J. 2009. The importance of niches for the maintenance of species diversity. Nature 461:254-257. DOI: 10.1038/nature08251

Martínez-Blancas A. 2014. ¿Existe una señal filogenética en la respuesta al disturbio antropogénico en especies vegetales? Implicaciones para la conservación. Tesis de maestría, Universidad Nacional Autónoma de México.

Martorell C, Martínez-López M. 2014. Informed dispersal in plants: Heterosperma pinnatum (Asteraceae) adjusts its dispersal mode to escape from competition and water stress. Oikos 123:225-231. DOI: $10.1111 / \mathrm{j} .1600-0706.2013 .00715 . \mathrm{x}$

Martorell C, Peters EM. 2009. Disturbance-response analysis: a method for rapid assessment of the threat to species in disturbed areas. Conservation Biology 23:377-387.

Mueller-Dombois D, Ellenberg H. 1974. Aims and methods of vegetation ecology. New York: John Wiley \& Sons. DOI: 10.1111/j.1523-1739.2008.01134.x

Myers N, Mittermeier RA, Mittermeier CG, da Fonseca GAB, Kent J. 2000. Biodiversity hotspots for conservation priorities. Nature 403:853-858. DOI: 10.1038/35002501

Preston FW. 1962. The canonical distribution of commonness and rarity: Part I. Ecology 43: 185-215. DOI: $10.2307 / 1931976$

Romero-Frizzi MÁ. 1996. El sol y la cruz: los pueblos indios de Oaxaca colonial. México DF: Centro de Investigaciones y Estudios Superiores en Antropología Social and Instituto Nacional Indigenista.

SEMARNAT 2003. Informe de la Situación del Medio Ambiente en México 2002. México DF: Secretaria de Medio Ambiente y Recursos Naturales.

Silvertown J. 2004. Plant coexistence and the niche. Trends in Ecology and Evolution 19:605-611. DOI: http://dx.doi.org/10.1016/j.tree.2004.09.003

Wilson JB, Peet RK, Dengler J, Pärtel M. 2012. Plant species richness: the world records. Journal of Vegetation Science 23:796-802. DOI: 10.1111/j.1654-1103.2012.01400.x

Wood SN. 2011. Fast stable restricted maximum likelihood and marginal likelihood estimation of semiparametric generalized linear models. Journal of the Royal Statistical Society Series B Statistical Methodology 73: 3-36. DOI: 10.1111/j.1467-9868.2010.00749.x 